Title:

\title{
NUCLEAR RECEPTORS IN TRANSGENERATIONAL EPIGENETIC INHERITANCE
}

Authors: Lilla Ozgyin, Edina Erdős, Dóra Bojcsuk and Balint L. Balint

Affiliation: University of Debrecen, Medical Faculty, Department of Biochemistry and Molecular Biology, Genomic Medicine and Bioinformatics Core Facility, Nagyerdei krt 98, 4012 Pf6, Debrecen, Hungary

Corresponding author: Balint L. Balint: lbalint@med.unideb.hu

\begin{abstract}
Nuclear Receptors are ligand-activated transcription factors that translate information about the lipid environment into specific genetic programs, a property that renders them good candidates to be mediators of rapid adaptation changes of a species. Lipid-based morphogens, endocrine hormones, fatty acids and xenobiotics might act through this class of transcription factors making them regulators able to fine-tune physiological processes. Here we review the basic concepts and current knowledge on the process whereby small molecules act through nuclear receptors and contribute to transgenerational changes. Several molecules shown to cause transgenerational changes like phthalates, BPA, nicotine, tributylin bind and activate nuclear receptors like ERs, androgen receptors, glucocorticoid receptors or PPAR $\gamma$. A specific subset of observations involving nuclear receptors has focused on the effects of environmental stress or maternal behaviour on the development of transgenerational traits. While these effects do not involve environmental ligands, they change the expression levels of Estrogen and glucocorticoid receptors of the second generation and consequently initiate an altered genetic program in the second generation. In this review we summarize the available literature about the role of nuclear receptors in transgenerational inheritance.
\end{abstract}


Keywords: nuclear receptors, epigenetic, transgenerational, Estrogen, Glucocorticoids 


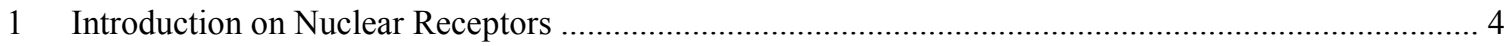

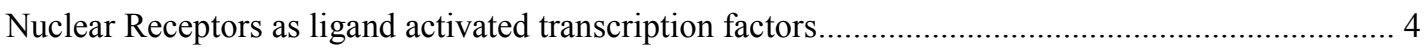

The general structure of NR-s with emphasis on the ER receptors....................................................... 5

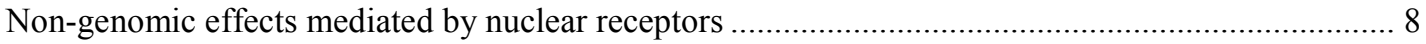

Non-ligand based effects involving nuclear receptors ....................................................................... 9

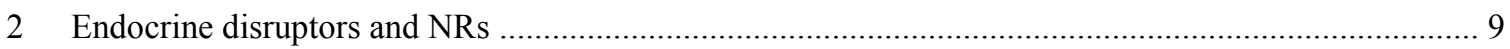

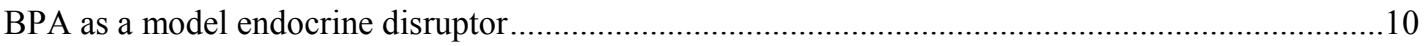

Involvement of PPAR $\gamma$ in transgenerational inheritance ..................................................................13

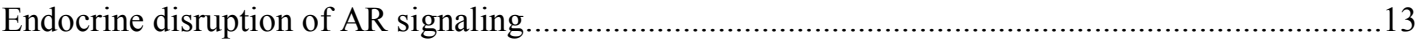

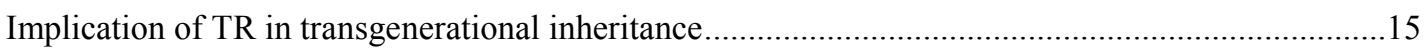

3 Transgenerational behavioural inheritance involving nuclear receptors .............................................15

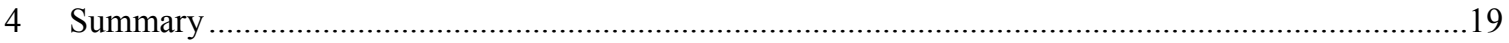

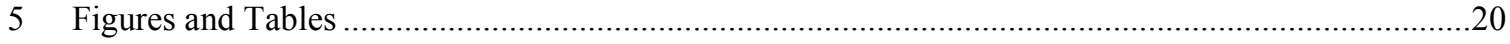

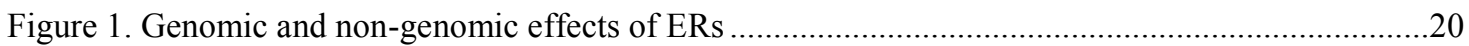

Figure 2. Potential mechanisms by which stress behaviour and nuclear receptors might be connected...21

Table 1 Concentration of BPA and phthalates used in some experiments in which transgenerational

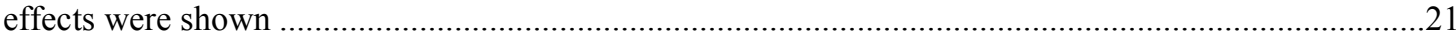

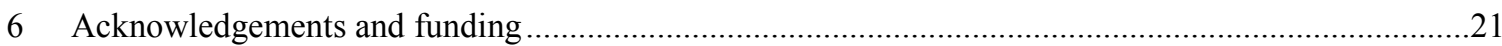

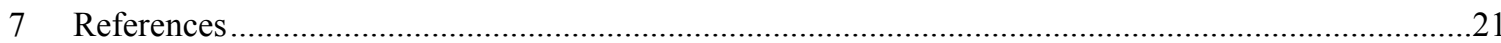




\section{Introduction on Nuclear Receptors}

While nuclear receptors (NR) were discovered more than 25 years ago (Giguere et al., 1988), the ligands that act through this transcription factor (TF) superfamily have been known for decades, e.g. Estrogen was discovered 85 years ago in 1929 by Adolf Butenand and Edward Doisy. In the following, years Edward Kendall isolated hormones from adrenal gland and by identification of cortisone the first medical application of steroid hormones was carried out. Intense research of the following decades elucidated the role of steroid hormones in basic physiological processes. The line of discoveries was expanded in the 1980s, by the advances in DNA sequencing and basic molecular biology technologies that allowed cloning of groups of proteins based on sequence homology. In the last 25 years, we have learned that NRs not only contribute to a wide variety of physiological and pathological processes but their activity is regulated in a very complex manner from transcription regulation through protein posttranslational modification and protein degradation. New findings increasingly support the concept that nuclear receptors are involved in transgenerational adaptive changes through epigenetic mechanisms.

\section{Nuclear Receptors as ligand activated transcription factors}

The classical view of nuclear receptors is that they are ligand-activated transcription factors that translate relevant information about the lipid environment into specific genetic programs in specific cells. The responder cells performing this translation of information from changes in the lipid environment to changes in gene expression express a specific subset of nuclear receptors that will be activated by some of the relevant lipids in the environment of the cell called ligands. The ligands are lipophilic substances that cause conformational changes in the protein and as a result the nuclear receptor will recruit coactivators with enzymatic activity that will turn on transcription of the regulated genes.

If transgenerational epigenetic mechanisms allow the adaptation of a species to rapid environmental changes as expressed in various studies (Burggren) nuclear receptors may likely be implicated in these adaptive mechanisms. Translating the lipid environment into modified genetic programs by nuclear 
receptors can change developmental, endocrine and metabolic mechanisms of the whole organism as described below.

The sensitivity of a cell to a specific ligand is determined by the specific subset of nuclear receptors expressed. Epigenetic and environmental factors can modify the expression level of nuclear receptors by several mechanisms e.g. changing chromatin conformation, DNA methylation. All these mechanisms together can shift the sensitivity of a cell regarding specific lipids. This mechanism of epigenetic regulation of expression levels was reported for several nuclear receptors e.g. the change in expression levels of ER and GR its effect upon maternal care, which has a lifelong effect on the sensitivity of the hypothalamic adrenocortical (HPA) axis and the overall and lifelong stress response of the offspring (Weaver et al., 2004). If activated by a specific ligand that binds nuclear receptors, a cell will perform a particular genetic programme based on the chromatin regions that are in an open chromatin conformation in the particular time point. The number of putative binding sites for a specific nuclear receptor in the human genome is by orders of magnitude higher than sites bound by a specific transcription factor. In the case of ER the number of putative binding sites is estimated to be in the range of one million (Liu and Lauffenburger) but others have found by bioinformatic tools a number of 71119 ERE sites (Bourdeau et al., 2004), while the MCF7 cell line has a number of ChIP Seq (Chromatin ImmunoPrecipitation followed by deep Sequencing) identified Estrogen Receptor (ER) binding sites on the order of tens of thousands (Lin et al., 2007) (Carroll et al., 2006). The difference between the putative binding sites and the sites occupied in a specific cell population by the receptor is caused by the accessibility of the binding sites for the available proteins in a particular cell. Epigenetic mechanisms might change the chromatin conformation of the cell through chromatin remodelling enzymes and heterochromatinization, triggered by DNA methylation and specific repressive histone marks (like H3K9 methylation or, H3K27 methylation) (Allis et al., 2006).

\section{The general structure of NR-s with emphasis on the ER receptors}

The general architecture of these receptors has the following features. On the $\mathrm{N}$ terminal region usually, we can locate an activating region (A/B region: $\mathrm{AF} 1)$ followed by a DNA binding domain (C region: $\mathrm{DBD})$, an 
unstructured hinge region (D) that binds to the ligand-binding domain (E) and on the $\mathrm{C}$ terminal end of the protein, a second helical-activating region (AF2).

The $\mathrm{N}$ terminal AF1 region

The $\mathrm{N}$ terminal AF1 region of the ER is one of the most variable regions of the NR family. For example in the case of ER $\alpha$ and $E R \beta$ these regions show less than $15 \%$ homology compared to the $98 \%$ homology of their DBDs (Le Romancer et al.). The AF1 regions of the protein are involved in coactivator binding and non ligand dependent activation of NRs. These protein stretches are disorganized, unfolded proteins and in many cases these regions are post translationally modified. E.g. in the case of the AF1 region for ER $\alpha$ at least 6 different serine phosphorylation sites were reported, with some of these modifications being initiated by estradiol binding, and others by different secondary messengers (Le Romancer et al.). The activity of ER-s on the AF2 region might be changed by a plethora of signals such as insulin, IGF-I, PMA, EGF, ROS and various estrogen-like ligands too. Regarding the estrogen-like activity of bisphenol A (BPA), the N terminal AF1 region of the ER was shown to be indispensable for the effect in parallel with the binding of BPA into the ligand-binding domain discussed later (Delfosse et al.).

The DNA Binding Domain (DBD)

The DBD is responsible for locating the NR in the genome to the recognition site and allows binding of zinc fingers to the DNA. According to the classical view, NRs act as dimers and due to this feature, the recognition site is comprised of two half sites with the classical AGGTCA being considered the recognized motif and a spacer of different length is found between the two half sites (Mangelsdorf et al., 1991) (Heery et al., 1994). The half sites can be in the same orientation and named in this case Direct Repeats or in the opposite orientation and named Inverted Repeats. The crystal structure of the ER $\alpha$ DBD was reported as early as 1990 (Schwabe et al., 1990). In the case of ERs, the DNA recognition site is called ERE (Estrogen Response Element) and consists of a 13-bp palindromic sequence GGTCAnnnTGACC named IR3 (Klinge, 2001) (Gruber et al., 2004). The DNA binding domain of ER $\alpha$ is subject to phosphorylation both in the serine and tyrosine residue modifications that influence the DNA binding and transcriptional activation properties of the ER. 
The hinge

The hinge region is involved in the dimerization of the NRs and for ER it was described that it might be posttranslationally modified in an estradiol dependent manner like the phosphorylation of the serine (Held et al.) or more interestingly like the acetylation in lysine residues with a position effect. Depending on the site of acetylation, DNA binding and transactivation is increased by acetylation at position K266/288 (Kim et al., 2006) but inhibited by the same posttranslational modification on the minor acetylation site K302/303 (Wang et al., 2001). Recently the methylation of the ER hinge region was reported at position K266 that acts in an inhibitory manner opposing the effect seen by K266 acetylation (Zhang et al.). For a detailed review of ER post translational modifications of ER $\alpha$ see (Le Romancer et al.) Interestingly arginine in position R260 was shown to be methylated by PRMT1 (protein arginine methyltransferase 1) through a non-genomic pathway initiated by Estrogen (Le Romancer et al., 2008) (Le Romancer et al.).

The LBD and AF2

The ligand-binding domain has a lipophilic ligand-binding pocket capable of binding the lipophilic ligands. Besides this role, the LBD provides the interaction surface for the binding of coactivator or corepressor proteins. It is made of $12 \alpha$ helices organized in a tree layered sandwich structure where the helix 12 is the AF2 and covers the ligand-binding cavity upon ligand binding. The receptor itself is considered to be in a loose structure stabilized by the protein-protein interactions and chemical skeleton of the ligand. Ligandbinding cavities can vary from $700 \AA^{3}$ in the case of Retinoid X Receptor alpha (RXR $\left.\alpha\right)$ to $1500 \AA^{3}$ in the case of Peroxisome Proliferator-activated Receptor gamma (PPAR $\gamma$ ). ROR $\alpha$ (retinoic acid-related orphan nuclear receptor alpha) has a structural lipid incorporated into the molecule (Kallen et al., 2004) and Nurr1 has no ligand-binding cavity at all (Wang et al., 2003).

The binding of ligand into the ligand-binding cavity very much depends on the properties of the particular nuclear receptor. As a general rule we can state that hormone receptors with higher affinity are more specific and have a smaller ligand-binding cavity, while metabolite sensors have larger ligand-binding pockets and very different ligands can bind to them with a lower affinity. 9-cis-retinoic acid fills $75 \%$ of the 
ligand-binding cavity of the Retinoid Acid Receptor alpha (RAR $\alpha$ ), molecule, while in the case of the metabolite sensor PPAR $\gamma$, the full synthetic agonist rosiglitazone, fills only $25 \%$ of the cavity (Gampe et al., 2000). Besides regular binding of the ligand into the hydrophobic pocket, non-canonical events can also occur. For example, some of the ligands can bind into the ligand-binding pocket in two different conformations like the eicosapentanoic acid for PPAR $\delta$ (Xu et al., 1999) or there are reports of covalent binding of the ligand into the pocket (Itoh et al., 2008).

In the case of the ER $\alpha$ ligand-binding cavity the hydrophobic ligand-binding cavity has polar regions on opposite ends anchoring the hydroxyl groups of estradiol (Ruff et al., 2000). The volume of the ligandbinding cavity is only $450 \AA^{3}$ with the estradiol occupying only $250 \AA^{3}$. While diethylstilbestrol (DES) has a similar binding to the cavity like estradiol, the antagonist tamoxifen displaces the helix 12 (AF2) and consequently interferes with the recruitment of coactivators. BPA was shown to occupy the ligand-binding pocket in a similar manner as estradiol with a canonical closing of the cavity by helix 12 (Delfosse et al.). On the other hand, Bisphenol $\mathrm{C}$ acts more like tamoxifen displacing the helix 12 and blocking the binding of the coactivator proteins.

ER $\alpha$ LBD was shown to be acetylated, sumoylated, and methylated on several lysine residues, phosphorylated on serine, threonine and tyrosine modifications being constitutively present or triggered by estradiol or EGF (epidermal growth factor). There were reported palmitoylation sites on the LBD of ER $\alpha$ and these modifications are crucial for the non-genomic reported effects of estrogen (Adlanmerini et al.)

\section{Non-genomic effects mediated by nuclear receptors}

Besides the classical view of ligand dependent transcription factors, important and relevant findings have been reported regarding the membrane bound effects of some of the nuclear receptors. In these cases the nuclear receptors are part of specific intracellular signalling pathways. For example, ER $\alpha$ has been shown to be palmitoylated and bound to the cytoplasmatic membrane, a feature involved in the normal functioning of the ovaries and a mutation in the palmitoylation site causes infertility (Adlanmerini et al.). This activity is not mediated through the ligand-binding transcription factor activity of the nuclear receptors but most 
likely involves, besides the palmitoylated ER, other proteins such as the membrane protein GPR30 and the SRC pathway (Raz et al., 2008).

\section{Non-ligand based effects involving nuclear receptors}

Early life events like maternal care and exposure to several other environmental factors have long been claimed to make substantial contribution to phenotypic traits of the offspring and some of them persist into adulthood. Although most traits are inherited through genetic material, there is an abundance evidence suggesting that another group of mechanisms, non-genomic in nature, that is, not coupled to transmission through the primary structure of DNA are involved. These mechanisms involve such modifications like DNA methylation, post-translational histone modifications and other regulatory information carriers contributing to the precise setting of gene expression patterns while providing plasticity to adequately respond to the ever-changing environment. Epigenetic transfer of information describes cell-to-cell as well as generation-to-generation inheritance. Various studies in animal models report that variability in the sensitive developmental period of pregnancy, including maternal malnutrition, exposure to stressful situations or negligent or abusive maternal care during the first week postpartum, has an impact on how offspring respond to stressful and novel situations and even after weaning. These behavioural responses are collectively linked to altered neuronal development and neuroendocrine features.

\section{Endocrine disruptors and NRs}

Since ERs are the most widely known to be involved in transgenerational inheritance, we will present most of the data about transgenerational inheritance through the example of ERs. Beside ERs we will present examples of other nuclear receptors like PPARs, VDR (Vitamin D Receptor) and TR (thyroid hormone receptor).

Several endocrine disruptors were shown to cause transgenerational changes. Extensive reviews on this topic can be found in the literature. In this review we will focus on the role of the nuclear receptors in mediating these effects. The most extensively studied endocrine disruptors are BPA, phthalates, Vinclozolin. 


\section{BPA as a model endocrine disruptor}

BPA is one of the extensively studied endocrine disruptors. BPA is used in plastic ware, medical tubing, food and water containers and is considered one of the most important endocrine disruptors present in our environment. Immense quantities of it are produced, approximately 3.2 million tons per year (Matsushima et al., 2007). A detailed review on BPA and nuclear receptors can be read here (Delfosse et al.)

BPA is considered to an endocrine disruptor targeting ER $\alpha$, although significant amounts of data suggest the involvement of other nuclear receptors in mediating the observed effects. While several endocrine disruptors were shown to have transgenerational effects, in many cases it is difficult to clearly establish the target of the molecules and the mode of action of them. Both endocrine hormones and endocrine disruptors can activate several of the nuclear receptors although at very different concentrations. For example, $\mathrm{EC}_{50}$ of estradiol is in the range of $2-5 \mathrm{pM}$ for ER $\alpha, 7-20 \mathrm{pM}$ for ER $\beta$ and $10 \mu \mathrm{M}$ for PXR. BPA seems to be a relatively promiscuous molecule, having an $\mathrm{EC}_{50}$ of $4 \mu \mathrm{M}$ for $\mathrm{ER} \alpha$ and $\mathrm{ER} \beta, 2 \mu \mathrm{M}$ for $\mathrm{RXR} \alpha$ and more than $10 \mu \mathrm{M}$ for PXR (le Maire et al.) (Matsushima et al., 2007). Besides activating ER $\alpha$, ER $\beta$, RXR $\alpha$ and PXR, several lines of evidence underlie the importance of ERR $\gamma$ in mediating the effects of BPA (Matsushima et al., 2007). BPA binds to the ERR $\gamma$ molecule and preserves its basal transcriptional activity. In the meantime, it protects the ERR $\gamma$ molecule against tamoxifen-driven inactivation. The IC50 for ERR $\gamma$ of the BPA is $13.4 \mathrm{nM}$, comparable to tamoxifen (10.3 nM) (Takayanagi et al., 2006). Regarding the ERR $\gamma$, not only do biochemical data confirm this effect but also the crystal structure of ERR $\gamma$ with BPA is available (Matsushima et al., 2007). In very high concentrations (in the $100 \mu \mathrm{M}$ range) BPA was shown to activate $\mathrm{AR}$, although the relevance of these data is questionable due to the fact that $100 \mu \mathrm{M}$ is a concentration far too high represent an environmental pollutant ( $\mathrm{Li}$ et al.). Halogenated forms of BPA were shown to activate PPAR $\gamma$ although in a 100 -fold higher concentration than rosiglitazone one of the most potent synthetic PPAR $\gamma$ agonists (Riu et al.). These findings based on ligand-binding biochemical assays and crystal structure data contradict some biological studies that reported an Estrogen-like effect at nanomolar concentrations suggesting the possibility that non-genomic mechanisms might be involved in mediating 
these effects. In order to separate classical Estrogen effects from non-genomic ones, a cell impermeable formulation of Estrogen, namely albumin bound estrogen was used (Bouskine et al., 2009).

In Table 1, we present the concentration of BPA and phthalates used in some experiments showing transgenerational effects.

Potential mechanisms by which BPA acts transgenerationally

The epigenetic effect of BPA was shown in the Agouti vy mouse model. BPA changed the coat colour of the mice due to change in methylation of the transposable sequence in the promoter of the Agouti gene. Moreover supplementing the food of the animals with methyl donors or the phytestrogen genistein, the effect was blocked (Dolinoy et al., 2007).

A similar change in DNA methylation was reported by Bromer et al. in mice treated with DES or BPA. These molecules through an in utero effect changed the HOXA10 expression level. The molecular mechanism was shown to decrease DNA methylation of the promoter of HOXA10 and increased ER $\alpha$ binding to the HOXA10 after in utero exposure to BPA. These effects persisted only in the offspring but not in the mice treated suggesting a clear transgenerational effect that implies a sensitive window during embryological development (Bromer et al.).

DNA methylation can change the expression level of the ER itself. Neonatal exposure to BPA caused hypermethylation of the promoter of ER in rat testes (Doshi et al.). These changes seem to be time- and cell-type dependent since in an opposite manner phthalates with estrogenic activity were shown to demethylate the promoter of the ER gene in MCF-7 and MCF10A cell lines (Kang and Lee, 2005).

A mechanism that might be responsible for the changes in DNA methylation involves changes in DNA methyltransferease expression levels. DNA methyltransferases were decreased by DES (dietylstilbestrol) after subcutaneous injection of DES in mice and at least five investigated genomic loci showed decreased DNA methylation in the uterus of the investigated mice (Sato et al., 2009). Interestingly the same group 
used similar methods and experimental setup to study the changes in DNA methyltransferase (DNMT) expression and DNA methylation in epididymis of mice and found altered but increased expression of DNMT-s. (Sato et al., 2006)

In some instances the transgenerational change is simply a sensitization of the organism towards a second signal. As an example, neonatal exposure of rats to BPA resulted in an increased incidence of prostate intraepithelial neoplasia (Ho et al., 2006). A similar priming effect was observed in BPA or DES exposed mice, in which progesterone treatment followed by estrogen resulted in a reduced proliferative response in the uterus (Varayoud et al., 2008).

Doherty et al. studied the molecular mechanisms by which BPA affects chromatin modifications in the MCF7 cell line, through and identified an increase in the expression of Enhancer of Zeste Homolog 2 (EZH2) and a concomitant increase in histone H3 trimethylation at lysine 27 (Doherty et al.). The role of EZH2 in the chromatin modifications by xenoestrogens was confirmed by the Walker group (Bredfeldt et al.) and complemented with the finding that these xenoestrogens act through the PI3K/AKT pathway through a non-genomic pathway. ER KO (knock-out) animals failed to present the same effects highlighting the importance of the ERs in these effects.

The mechanism of changed hormonal response could be explained by the changed expression of nuclear receptor coregulators after exposure to BPA. Perinatal exposure to BPA of rats caused changes in the expression levels of key components of nuclear receptor signalling namely the coactivators and corepressors that mediate the conformational changes caused by ligand binding towards the transcriptional machinery. These changes in NCoR and SRC-1 and GRIP expression were seen in protein levels in the testes of F1, F2 and F3 generations with a reduction in NCoR and increase in GRIP-1 levels. (Salian et al., 2009) 


\section{Involvement of PPAR $\gamma$ in transgenerational inheritance}

Several other nuclear receptors besides ERs were shown to be involved in transgenerational inheritance. We will present some data about PPAR $\gamma$ and AR.

Regarding PPAR $\gamma$, Torday et al. presented data indicating that the asthma phenotype can be transmitted transgenerationally after in utero exposure to smoke in rats. (Krebs et al.; Liu et al.; Liu et al.; Rehan et al.; Sakurai et al.). They showed that perinatal nicotine exposure induced transmission of childhood asthma phenotype in F3 generations. In F3 offspring (third-generations of the exposed F0 gestating dams) the authors investigated pulmonary function, tracheal tension and measured the PPAR $\gamma$ mRNA and protein levels in cultured fibroblasts, as well. Their results suggest that the functional effects of nicotine are associated with the increased expression of fibronectin and downregulation of PPAR $\gamma$ expression in isolated lung fibroblasts.

Tributyltin (TBT) was used for decades in ship construction as a biocide. It later became evident that it negatively affects not only algae but several other species as well. Recently it was shown that TBT is a PPAR $\gamma$ and RXR activator. Kirchner (Kirchner et al.) demonstrated epigenetic changes in the PPAR $\gamma$ target gene and consequently the Blumberg group (Chamorro-Garcia et al.) aimed to determine whether prenatal exposure of the environmental obesogen TBT were heritable in F2 and F3 generations. They focused on the effects of this exposure i.e. on fat depot weights, adipocyte number and size and these studies reported that prenatal TBT exposure of pregnant animals caused transgenerational effects on adipose depot weight, adipocyte size and number, having an obesity promoting effect. The increase of the white adipose tissue depot size in mice occurs via activation of PPAR $\gamma$. These results show that early-life obesogen exposure can have lasting effects, and how they could be passed on to subsequent generations as they persisted until at least the F3 generation. (Chamorro-Garcia et al.)

\section{Endocrine disruption of AR signaling}

Vinclozolin, a fungicide commonly used in agriculture was shown to act as an AR ligand in several studies. The experiments with the endocrine disruptor vinclozolin were performed both in rats and mice and tested 
equally in the male and female reproductive system, thus engendering many arguments and counter arguments related to these findings.

First, Anway et al. studied the effects of vinclozolin with methoxychlor, a pesticide containing metabolites with estrogenic, anti-estrogenic and antiandrogenic activities (Gaido et al., 1999) (Anway et al., 2005). Exposure to these chemicals in the late embryonic or early postnatal period causes changes in the sexual differentiation and reproductive function of the F1 generation (Chapin et al., 1997). Anway et al. treated only F0 outbred Sprague Dawley (SD) female rats with vinclozolin or methoxychlor and examined the adult male rats in the subsequent generations $(\mathrm{F} 1-\mathrm{F} 4)$. In the case of vinclozin treatment, the male animals had increased spermatogenic cell apoptosis and the sperm quality was also negatively affected. A similar effect was seen in animals after methoxychlor exposure in both F1 and F2 animals. The testis histology in the vinclozolin treated F3 generation demonstrates a loss of normal spermatogenesis and abnormal morphology. In another study, the group reported that embryonic exposure with vinclozolin can cause defects not only in subfertility but also a number of multiple transgenerational disease states or abnormalities, including the defects of immune system, prostate- and kidney diseases, tumour development, as well as inflammation, increased blood markers for renal lesion (Anway et al., 2006)

These findings were questioned by Schneider and his colleagues. In a similar experimental system, they reported that vinclozolin has no transgenerational effect on the male reproductive system (Schneider et al., 2008). The effect of vinclozolin on the methylation pattern of imprinted genes in mouse sperm was later reported by several independent groups (Stouder and Paoloni-Giacobino) (Inawaka et al., 2009) (GuerreroBosagna et al.) (Nilsson et al., 2008).

In addition to the effects on sperm, an interesting transgenerational effect of vinclozolin treatment was seen in rats. Females were able to discriminate based on the odor of males exposed to vinclozolin. Both males and females originating from females treated with vinclozolin in a $-\mathrm{F} 3$ generation. Females preferred males that did not originate from vinclozolin treated progenitors while males did not have this preference (Crews et al., 2007). 


\section{Implication of TR in transgenerational inheritance}

The Shiao group investigated whether transgenerational carcinogenesis involves epigenetic mechanisms. The authors observed that the offspring of fathers treated with metal derivatives - in this case with Chromium (III) chloride - had higher levels of serum thyroid hormone. In the offspring, some genes that play key roles in growth and tumour suppression had changed expression ratios, which correlated with the serum triiodothyronine (T3) levels. (Cheng et al., 2004)

\section{Transgenerational behavioural inheritance involving nuclear receptors}

Adverse environmental effects in early life, mainly subnormal mother-infant interactions appear to be critical to the developing organism, in the area of neuronal development, social behaviour cognitive abilities and response to acute or chronic stress. This phenomenon has been studied in a wide range of species, such as rats, mice, chickens, some non-human primates and also on humans relating natural or simulated low-level of maternal care to pathological changes affecting adults. In humans, maternal rejection, neglect or abusive behaviour is found to be associated with depression (Batten et al., 2004), schizophrenia (Read et al., 2005), anxiety-related disorders (Phillips et al., 2005), diabetes and cardiovascular disease (Batten et al., 2004), (Goodwin and Stein, 2004).

Regarding maternal care, long-term effects affect both male and female pups and seem to be passed matrilineally from mothers to female offspring (McCarty and Lee, 1996), (Fairbanks, 1989). The extent of maternal care is an inherent feature of each mother and does not substantially differ between litters and is normally defined as the frequency of licking and grooming (LG) and arched-back nursing (ABN) or both (LG-ABN) in the first few sensitive days of life postpartum (Champagne et al., 2003a). Three distinct groups were defined artificially based on naturally occurring LG variations between mothers, namely Low LG, Middle LG and High LG dams. High LG mothers are females whose mean LG frequency in days 1-6 postpartum is greater than $1 \mathrm{SD}$ above the mean, Low LG mothers are females whose mean frequency of LG is greater than 1 SD below the mean, and Mid LG mothers are defined as females whose mean 
frequency is within $1 \mathrm{SD}$ of the mean (Champagne et al., 2003a). Several experiments strengthened the presumption that licking and grooming has a significant role in programming the pups' later response to acute stress and in developing socio-behavioural features for adulthood. For example, the offspring of high LG mothers showed modest response to acute stress and were less fearful than pups of low LG mothers (Francis and Meaney, 1999). Strikingly, when doing cross-fostering experiments, biological offspring of Low LG mothers reared by high LG mothers in the same litter where the same mother reared her own biological offspring were not distinguishable from one another regarding stress reactivity (Francis et al., 1999), (Barbazanges et al., 1996), (Caldji et al., 1998). These experiments clearly underpinned the theory of non-genetic transmission of maternal behaviour, making the classification of the foster and not the biological dam predictive of the female offspring's stress response and later maternal behaviour. In point of fact, female offspring reared by the high LG dam exert more frequent LG-ABN compared with pups reared by low LG mothers (Champagne et al., 2003a). Also, if the frequency of licking/grooming were artificially induced by a technique called handling, the pups showed significantly lower stress reactivity and fearfulness compared to their non-handled counterparts and become High LG mothers (Meerlo et al., 1999), (Vallee et al., 1997).

Molecular mechanisms underlying "inheritance" of maternal care and stress resilience patterns have been extensively investigated in rats and mice. Formation of epigenetic patterns during the first few days after birth is critical to stabilize individual-specific neurophysiological attributions. Both neuronal and endocrine elements of the HPA axis play a role in multiple layers of stress-reactivity regulation. Two main nuclear receptors have been linked to these mechanisms as critical elements of the molecular regulatory system, namely the GR and ER $\alpha$. The causative role of corticosteroids in triggering stress and maintaining responsiveness have long been postulated, so the receptors accepting and translating these signals are presumably the key molecular players in these mechanisms.

GR mediates the transcriptional effects of corticosteroids, like corticosterone (CORT) in rodents and cortisol in humans (Rousseau and Baxter, 1979). Mineralocorticoid receptors seem to play the role of a regulator of basal cortisol levels and GR comes into the picture when hormone levels are higher (Kolber et al., 2008). Stress activates the HPA axis via neuronal circuits in the hypothalamic paraventricular nucleus 
$(\mathrm{PVN})$ where Corticotropin Releasing Hormone (CRH) expression is induced and subsequently plasma adrenocorticotropin (ACTH) and corticosteroid levels rise (Kolber et al., 2008). GR receives the corticosteroid signal in the brain and acts as an inhibitor to CRH expression to provide a negative feedback mechanism to maintain HPA axis homeostasis as demonstrated by findings showing that reduced levels of GR mRNA is associated with attenuated stress responsivity (McEwen, 2007) (Tsigos and Chrousos, 2002), (Keller-Wood and Dallman, 1984). Indeed, variable quality in maternal care seems to shift the function of the HPA axis with effects on plasma CORT and ACTH levels through altered CRH negative feedback sensitivity and Arginine-vasopressin (AVP) expression, triggered by altered hippocampal GR expression (Ladd et al., 2004).

The indispensable role of GR in maintaining physiological stress responses and mental wellbeing has been demonstrated using a mouse model overexpressing GR in the brain (Ridder et al., 2005). The strain shows no behavioural differences in basal conditions and lower sensitivity to stress-induced alterations compared to control animals. A GR underexpressing model, however, after immobilization test showed increased helplessness and stress coping deficits. Neuroendocrine tests also confirmed decreased CRH feedbacksensitivity in the latter model; given after dexamethasone injection, GR $+/$ - mice showed significantly higher CORT levels than control animals, while GR overexpressing mice showed significantly reduced peak levels of CORT (Sapolsky et al., 1984). In rats, biological offspring of pups reared by Low LG mothers appeared to show decreased levels of GR in AVP, which would influence HPA axis feedback since glucocorticoid sensitivity in the brain is limited by the available intracellular GR (Liu et al., 1997) (Caldji et al., 1998). Handling experiments increasing mother-infant interactions through more frequent and longer LG periods showed that pups exposed to daily handling showed significantly higher binding of $3 \mathrm{H}-$ dexamethasone in the hippocampus (Meaney et al., 1985) and higher levels of GR. In humans suffering from major depression, elevated cerebrospinal fluid CRH levels were observed and diminished GR expression or constrained function is responsible for the deficient feedback of cortisol, suggesting that corticosteroids affect a wide-range of behavioural concerns in humans as well (Watts, 2005). 
Recent evidence shows that decreased GR expression and derepressed CRH in the PVN is linked to increased GR promoter methylation documented in both rodents and humans. Specific exon $1_{7}$ in the promoter of the GR gene in rodents and the corresponding human homolog exon $1_{\mathrm{F}}$ of $G R$ bear the same type of methylation pattern if the subject of the study was exposed to adverse early-life events (Radtke et al.) (McGowan et al., 2009).

In rats, Weaver and colleagues showed that differential methylation can be observed comparing offspring of Low and High LG mothers in rats, and the alteration in methylation status is also coupled with differential NGFI-A binding in brain tissues and is sustained to adulthood. In the pups that lacked LG in the first days after birth, DNA hypermethylation co-occurs with hypoacetylation of histones at the promoter of the GR gene. This methylation blocks the binding of nerve growth factor-inducible factor A (NGFI-A) transcription factor binding to the GR promoter. Interestingly the methylation of the NGFI-A genomic binding site could be suspended by central infusion of HDAC (Histone Deacetylase) inhibitor TSA (Trichostatin A) during the first days of life (Weaver et al., 2004). TSA infusion not only blocked methylation of the specific site but also the group differences in newborn rats caused by high or low level of LG disappeared.

Estrogen plays an indispensable role in regulating many aspects of sexual function in most mammals. Estrogen is also related to the emergence of maternal care, working in concert with other hormones like progesterone and prolactin, with precisely tuned blood levels during pregnancy. Besides hormonal components, infant-based stimulation after birth is another critical inductor of maternal care (Rosenblatt, 1994). Earlier studies showed that introducing Estrogen-benzoate into the Medial Preoptic Area (MPOA) of pregnancy-terminated, ovariectomized and hysterectomized female rats stimulates the onset of maternal care 2 days after treatment (Siegel and Rosenblatt, 1975). Also, implants of estrogen in the preoptic area stimulates maternal behaviour measured by the responsivity of the mother to foster pups in rats (Fahrbach and Pfaff, 1986). Interestingly, maternal behaviour could be triggered in gonadectomised male rats after hormonal simulation of pregnancy either when estradiol-benzoate capsules were implanted into the MPOA or injected into peripheral blood (Rosenblatt and Ceus, 1998). These findings suggested that maternal 
behaviour would be mediated by ER activity. During pregnancy, ER expression is shown to be elevated at both the mRNA (DonCarlos, 1996) and protein level (Wagner and Morrell, 1996). ER $\alpha$ KO mice showed impairments in maternal care-related behaviours among other specific phenotypic traits (Ogawa et al., 1998). Mice with MPOA siRNA silencing of ER $\alpha$ have similar phenotypes regarding maternal care than do KO mice (Ribeiro et al.). In lactating, High LG female rats, ER $\alpha$ expression is higher in Low LG mothers. Likewise, adult virgin female offspring of High LG mothers express higher amounts of ER $\alpha$ than those of a Low LG mother. Moreover, High LG mothers showed higher estrogen sensitivity compared to Low LG mothers, as measured by increased cFos-reactivity (Champagne et al., 2003b). These findings are consistent with results claiming that oxytocin is a central component of maternal care and is transcriptionally induced by estrogen. In ovariectomized female mice, when estrogen is introduced, only daughters of High LG mothers responded to estrogen by increased oxytocin-oxytocin receptor binding (46). The ER $\alpha 1 \mathrm{~b}$ promoter seems to be responsible for differential ER $\alpha$ expression, since Low LG mothers showed significantly higher promoter methylation than Low LG mothers did, and the methylation site overlaps with a STAT5 motif, which abolishes STAT5 binding based on the ChIP signal (Champagne et al., 2006). ERs seem to mediate the maternal care component, while GR regulates behavioural and endocrine stress responsivity and both are modulated via behavioural transmission through not clearly identified mechanisms that implicate epigenetic components.

\section{Summary}

In the last couple of years our tools to study epigenetic mechanisms in a whole genome approach at a relatively low cost allowed us to fine map the events that occur on the chromatin level in several cell types. Large consortia like the ENCODE, FANTOM or the 1000 Genomes Project made significant contribution to our understanding on how genes are regulated and what enzymatic steps are involved in this regulation. It has to be mentioned that on a gene-to-phenotype approach the results of the investigations are relatively modest due to the fact that many pathways in the body are redundant and that several disease states lack well performing animal models. In the case of NRs we have accumulated significant amount of data on how transcription is regulated by probably a dozen of NRs, but we have to admit that we have very few 
well established transgenerational models that address the role of NRs in transgenerational inheritance.

In order to move further on this road we need to systematically investigate the role of different NRs during oogenesis and spermatogenesis on the subsequent generations.

In order to better understand the toxicity of some molecules that we use regularly in industrial processes and that might be endocrine disruptors xenobiotics need to be investigated not only in cellular assays or animal experiments that monitor toxicity and lethality but also in animal models that are suitable to monitor transgenerational effects e.g. the Agouti vy model that is a methylation sensor.

Regarding ER in special we need to overcome the original concept that ER can act only as a classical NR since more and more data suggests that post translational modifications, AF1 activation and membrane bound effects are contributing to the overall function of estrogens. To address these issues we need new antibodies that recognize modified nuclear receptors and are suitable for advanced technologies like advanced microscopy and functional genomic investigations.

One of the most promising field of investigations in the next decade will be probably the studies in the field of neuroscience. While both the nuclear receptor field and the field transcription regulation made significant contribution to our actual knowledge in the field of metabolism or immune regulation they could contribute massively to the field of neuroscience too.

In the next couple of years probably by using new transgenerational models from all the previously mentioned fields we will be able to better understand how our decisions affect on a biological basis the upcoming generations.

\section{$5 \quad$ Figures and Tables}

\section{Figure 1. Genomic and non-genomic effects of ERs}

ERs can act on transcription through several pathways. Histone methylation by EZH2 can block transcription and acetylation by p300 might activate it. DNMT-s are methylating specific regions in the genome that might block transctiption. EDC stands for endocrine disrupting chemicals. 
Figure 2. Potential mechanisms by which stress behaviour and nuclear receptors might be connected

Lack of licking and grooming in the first days of life can cause aberrant methylation of the GR regulatory region that will have a whole life effect. This aberrant methylation can be prevented by central infusion of TSA.

Table 1 Concentration of BPA and phthalates used in some experiments in which transgenerational effects were shown

\section{Acknowledgements and funding}

Balint L. Balint is a Szodoray fellow of the University of Debrecen Medical Faculty and a Magyary Zoltán fellow supported by the TÁMOP 4.2.4.A/2-11-1-2012-0001 grant implemented through the New Hungary Development Plan co-financed by the European Social Fund and the European Regional Development Fund. Jim Hesson revised the English.

\section{$7 \quad$ References}

Adlanmerini, M., Solinhac, R., Abot, A., Fabre, A., Raymond-Letron, I., Guihot, A. L., Boudou, F., Sautier, L., Vessieres, E., Kim, S. H., Liere, P., Fontaine, C., Krust, A., Chambon, P., Katzenellenbogen, J. A., Gourdy, P., Shaul, P. W., Henrion, D., Arnal, J. F. and Lenfant, F. Mutation of the palmitoylation site of estrogen receptor alpha in vivo reveals tissue-specific roles for membrane versus nuclear actions. Proc Natl Acad Sci U S A 111, E283-90.

Allis, C. D., Jenuwein, T. and Reinberg, D. (2006) Epigenetics, Cold Spring Harbor Laboratory Press, Cold Spring Harbor, N.Y.

Anway, M. D., Cupp, A. S., Uzumcu, M. and Skinner, M. K. (2005) Epigenetic transgenerational actions of endocrine disruptors and male fertility. Science 308, 1466-9.

Anway, M. D., Leathers, C. and Skinner, M. K. (2006) Endocrine disruptor vinclozolin induced epigenetic transgenerational adult-onset disease. Endocrinology 147, 5515-23.

Barbazanges, A., Vallee, M., Mayo, W., Day, J., Simon, H., Le Moal, M. and Maccari, S. (1996) Early and later adoptions have different long-term effects on male rat offspring. J Neurosci 16, 7783-90.

Batten, S. V., Aslan, M., Maciejewski, P. K. and Mazure, C. M. (2004) Childhood maltreatment as a risk factor for adult cardiovascular disease and depression. J Clin Psychiatry 65, 249-54. 
Bourdeau, V., Deschenes, J., Metivier, R., Nagai, Y., Nguyen, D., Bretschneider, N., Gannon, F., White, J. H. and Mader, S. (2004) Genome-wide identification of high-affinity estrogen response elements in human and mouse. Mol Endocrinol 18, 1411-27.

Bouskine, A., Nebout, M., Brucker-Davis, F., Benahmed, M. and Fenichel, P. (2009) Low doses of bisphenol A promote human seminoma cell proliferation by activating PKA and PKG via a membrane Gprotein-coupled estrogen receptor. Environ Health Perspect 117, 1053-8.

Bredfeldt, T. G., Greathouse, K. L., Safe, S. H., Hung, M. C., Bedford, M. T. and Walker, C. L. Xenoestrogen-induced regulation of EZH2 and histone methylation via estrogen receptor signaling to PI3K/AKT. Mol Endocrinol 24, 993-1006.

Bromer, J. G., Zhou, Y., Taylor, M. B., Doherty, L. and Taylor, H. S. Bisphenol-A exposure in utero leads to epigenetic alterations in the developmental programming of uterine estrogen response. FASEB $J 24$, 2273-80.

Burggren, W. W. Epigenetics as a source of variation in comparative animal physiology - or - Lamarck is lookin' pretty good these days. J Exp Biol 217, 682-9.

Caldji, C., Tannenbaum, B., Sharma, S., Francis, D., Plotsky, P. M. and Meaney, M. J. (1998) Maternal care during infancy regulates the development of neural systems mediating the expression of fearfulness in the rat. Proc Natl Acad Sci U S A 95, 5335-40.

Carola, V., D'Olimpio, F., Brunamonti, E., Mangia, F. and Renzi, P. (2002) Evaluation of the elevated plusmaze and open-field tests for the assessment of anxiety-related behaviour in inbred mice. Behav Brain Res $134,49-57$.

Carroll, J. S., Meyer, C. A., Song, J., Li, W., Geistlinger, T. R., Eeckhoute, J., Brodsky, A. S., Keeton, E. K., Fertuck, K. C., Hall, G. F., Wang, Q., Bekiranov, S., Sementchenko, V., Fox, E. A., Silver, P. A., Gingeras, T. R., Liu, X. S. and Brown, M. (2006) Genome-wide analysis of estrogen receptor binding sites. Nat Genet 38, 1289-97.

Chamorro-Garcia, R., Sahu, M., Abbey, R. J., Laude, J., Pham, N. and Blumberg, B. Transgenerational inheritance of increased fat depot size, stem cell reprogramming, and hepatic steatosis elicited by prenatal exposure to the obesogen tributyltin in mice. Environ Health Perspect 121, 359-66.

Champagne, F. A., Francis, D. D., Mar, A. and Meaney, M. J. (2003a) Variations in maternal care in the rat as a mediating influence for the effects of environment on development. Physiol Behav 79, 359-71.

Champagne, F. A., Weaver, I. C., Diorio, J., Dymov, S., Szyf, M. and Meaney, M. J. (2006) Maternal care associated with methylation of the estrogen receptor-alphalb promoter and estrogen receptor-alpha expression in the medial preoptic area of female offspring. Endocrinology 147, 2909-15.

Champagne, F. A., Weaver, I. C., Diorio, J., Sharma, S. and Meaney, M. J. (2003b) Natural variations in maternal care are associated with estrogen receptor alpha expression and estrogen sensitivity in the medial preoptic area. Endocrinology 144, 4720-4.

Chapin, R. E., Harris, M. W., Davis, B. J., Ward, S. M., Wilson, R. E., Mauney, M. A., Lockhart, A. C., Smialowicz, R. J., Moser, V. C., Burka, L. T. and Collins, B. J. (1997) The effects of perinatal/juvenile methoxychlor exposure on adult rat nervous, immune, and reproductive system function. Fundam Appl Toxicol 40, 138-57.

Cheng, R. Y., Hockman, T., Crawford, E., Anderson, L. M. and Shiao, Y. H. (2004) Epigenetic and gene expression changes related to transgenerational carcinogenesis. Mol Carcinog 40, 1-11.

Crews, D., Gore, A. C., Hsu, T. S., Dangleben, N. L., Spinetta, M., Schallert, T., Anway, M. D. and Skinner, M. K. (2007) Transgenerational epigenetic imprints on mate preference. Proc Natl Acad Sci U S A $104,5942-6$.

Delfosse, V., Grimaldi, M., le Maire, A., Bourguet, W. and Balaguer, P. Nuclear receptor profiling of bisphenol-A and its halogenated analogues. Vitam Horm 94, 229-51. 
Delfosse, V., Grimaldi, M., Pons, J. L., Boulahtouf, A., le Maire, A., Cavailles, V., Labesse, G., Bourguet, W. and Balaguer, P. Structural and mechanistic insights into bisphenols action provide guidelines for risk assessment and discovery of bisphenol A substitutes. Proc Natl Acad Sci U S A 109, 14930-5.

Doherty, L. F., Bromer, J. G., Zhou, Y., Aldad, T. S. and Taylor, H. S. In utero exposure to diethylstilbestrol (DES) or bisphenol-A (BPA) increases EZH2 expression in the mammary gland: an epigenetic mechanism linking endocrine disruptors to breast cancer. Horm Cancer 1, 146-55.

Dolinoy, D. C., Huang, D. and Jirtle, R. L. (2007) Maternal nutrient supplementation counteracts bisphenol A-induced DNA hypomethylation in early development. Proc Natl Acad Sci U S A 104, 13056-61.

DonCarlos, L. L. (1996) Developmental profile and regulation of estrogen receptor (ER) mRNA expression in the preoptic area of prenatal rats. Brain Res Dev Brain Res 94, 224-33.

Doshi, T., Mehta, S. S., Dighe, V., Balasinor, N. and Vanage, G. Hypermethylation of estrogen receptor promoter region in adult testis of rats exposed neonatally to bisphenol A. Toxicology 289, 74-82.

Fahrbach, S. E. and Pfaff, D. W. (1986) Effect of preoptic region implants of dilute estradiol on the maternal behavior of ovariectomized, nulliparous rats. Horm Behav 20, 354-63.

Fairbanks, L. A. (1989) Early experience and cross-generational continuity of mother-infant contact in vervet monkeys. Dev Psychobiol 22, 669-81.

Francis, D., Diorio, J., Liu, D. and Meaney, M. J. (1999) Nongenomic transmission across generations of maternal behavior and stress responses in the rat. Science 286, 1155-8.

Francis, D. D. and Meaney, M. J. (1999) Maternal care and the development of stress responses. Curr Opin Neurobiol 9, 128-34.

Gaido, K. W., Leonard, L. S., Maness, S. C., Hall, J. M., McDonnell, D. P., Saville, B. and Safe, S. (1999) Differential interaction of the methoxychlor metabolite 2,2-bis-(p-hydroxyphenyl)-1,1,1-trichloroethane with estrogen receptors alpha and beta. Endocrinology 140, 5746-53.

Gampe, R. T., Jr., Montana, V. G., Lambert, M. H., Miller, A. B., Bledsoe, R. K., Milburn, M. V., Kliewer, S. A., Willson, T. M. and Xu, H. E. (2000) Asymmetry in the PPARgamma/RXRalpha crystal structure reveals the molecular basis of heterodimerization among nuclear receptors. Mol Cell 5, 545-55.

Giguere, V., Yang, N., Segui, P. and Evans, R. M. (1988) Identification of a new class of steroid hormone receptors. Nature 331, 91-4.

Goodwin, R. D. and Stein, M. B. (2004) Association between childhood trauma and physical disorders among adults in the United States. Psychol Med 34, 509-20.

Gruber, C. J., Gruber, D. M., Gruber, I. M., Wieser, F. and Huber, J. C. (2004) Anatomy of the estrogen response element. Trends Endocrinol Metab 15, 73-8.

Guerrero-Bosagna, C., Covert, T. R., Haque, M. M., Settles, M., Nilsson, E. E., Anway, M. D. and Skinner, M. K. Epigenetic transgenerational inheritance of vinclozolin induced mouse adult onset disease and associated sperm epigenome biomarkers. Reprod Toxicol 34, 694-707.

Heery, D. M., Pierrat, B., Gronemeyer, H., Chambon, P. and Losson, R. (1994) Homo- and heterodimers of the retinoid X receptor (RXR) activated transcription in yeast. Nucleic Acids Res 22, 726-31.

Held, J. M., Britton, D. J., Scott, G. K., Lee, E. L., Schilling, B., Baldwin, M. A., Gibson, B. W. and Benz, C. C. Ligand binding promotes CDK-dependent phosphorylation of ER-alpha on hinge serine 294 but inhibits ligand-independent phosphorylation of serine 305. Mol Cancer Res 10, 1120-32.

Ho, S. M., Tang, W. Y., Belmonte de Frausto, J. and Prins, G. S. (2006) Developmental exposure to estradiol and bisphenol A increases susceptibility to prostate carcinogenesis and epigenetically regulates phosphodiesterase type 4 variant 4 . Cancer Res 66, 5624-32.

Inawaka, K., Kawabe, M., Takahashi, S., Doi, Y., Tomigahara, Y., Tarui, H., Abe, J., Kawamura, S. and Shirai, T. (2009) Maternal exposure to anti-androgenic compounds, vinclozolin, flutamide and 
procymidone, has no effects on spermatogenesis and DNA methylation in male rats of subsequent generations. Toxicol Appl Pharmacol 237, 178-87.

Itoh, T., Fairall, L., Amin, K., Inaba, Y., Szanto, A., Balint, B. L., Nagy, L., Yamamoto, K. and Schwabe, J. W. (2008) Structural basis for the activation of PPARgamma by oxidized fatty acids. Nat Struct Mol Biol $15,924-31$.

Kallen, J., Schlaeppi, J. M., Bitsch, F., Delhon, I. and Fournier, B. (2004) Crystal structure of the human RORalpha Ligand binding domain in complex with cholesterol sulfate at 2.2 A. J Biol Chem 279, 14033-8.

Kanari, K., Kikusui, T., Takeuchi, Y. and Mori, Y. (2005) Multidimensional structure of anxiety-related behavior in early-weaned rats. Behav Brain Res 156, 45-52.

Kang, S. C. and Lee, B. M. (2005) DNA methylation of estrogen receptor alpha gene by phthalates. $J$ Toxicol Environ Health A 68, 1995-2003.

Keller-Wood, M. E. and Dallman, M. F. (1984) Corticosteroid inhibition of ACTH secretion. Endocr Rev 5, $1-24$.

Kim, M. Y., Woo, E. M., Chong, Y. T., Homenko, D. R. and Kraus, W. L. (2006) Acetylation of estrogen receptor alpha by p300 at lysines 266 and 268 enhances the deoxyribonucleic acid binding and transactivation activities of the receptor. Mol Endocrinol 20, 1479-93.

Kirchner, S., Kieu, T., Chow, C., Casey, S. and Blumberg, B. Prenatal exposure to the environmental obesogen tributyltin predisposes multipotent stem cells to become adipocytes. Mol Endocrinol 24, 526-39.

Klinge, C. M. (2001) Estrogen receptor interaction with estrogen response elements. Nucleic Acids Res 29, 2905-19.

Kolber, B. J., Wieczorek, L. and Muglia, L. J. (2008) Hypothalamic-pituitary-adrenal axis dysregulation and behavioral analysis of mouse mutants with altered glucocorticoid or mineralocorticoid receptor function. Stress 11, 321-38.

Krebs, M., Sakurai, R., Torday, J. S. and Rehan, V. K. Evidence for in vivo nicotine-induced alveolar interstitial fibroblast-to-myofibroblast transdifferentiation. Exp Lung Res 36, 390-8.

Ladd, C. O., Huot, R. L., Thrivikraman, K. V., Nemeroff, C. B. and Plotsky, P. M. (2004) Long-term adaptations in glucocorticoid receptor and mineralocorticoid receptor mRNA and negative feedback on the hypothalamo-pituitary-adrenal axis following neonatal maternal separation. Biol Psychiatry 55, 367-75.

le Maire, A., Bourguet, W. and Balaguer, P. A structural view of nuclear hormone receptor: endocrine disruptor interactions. Cell Mol Life Sci 67, 1219-37.

Le Romancer, M., Poulard, C., Cohen, P., Sentis, S., Renoir, J. M. and Corbo, L. Cracking the estrogen receptor's posttranslational code in breast tumors. Endocr Rev 32, 597-622.

Le Romancer, M., Treilleux, I., Bouchekioua-Bouzaghou, K., Sentis, S. and Corbo, L. Methylation, a key step for nongenomic estrogen signaling in breast tumors. Steroids 75, 560-4.

Le Romancer, M., Treilleux, I., Leconte, N., Robin-Lespinasse, Y., Sentis, S., Bouchekioua-Bouzaghou, K., Goddard, S., Gobert-Gosse, S. and Corbo, L. (2008) Regulation of estrogen rapid signaling through arginine methylation by PRMT1. Mol Cell 31, 212-21.

Li, J., Ma, M. and Wang, Z. In vitro profiling of endocrine disrupting effects of phenols. Toxicol In Vitro 24, 201-7.

Lin, C. Y., Vega, V. B., Thomsen, J. S., Zhang, T., Kong, S. L., Xie, M., Chiu, K. P., Lipovich, L., Barnett, D. H., Stossi, F., Yeo, A., George, J., Kuznetsov, V. A., Lee, Y. K., Charn, T. H., Palanisamy, N., Miller, L. D., Cheung, E., Katzenellenbogen, B. S., Ruan, Y., Bourque, G., Wei, C. L. and Liu, E. T. (2007) Wholegenome cartography of estrogen receptor alpha binding sites. PLoS Genet 3, e87.

Liu, D., Diorio, J., Tannenbaum, B., Caldji, C., Francis, D., Freedman, A., Sharma, S., Pearson, D., Plotsky, P. M. and Meaney, M. J. (1997) Maternal care, hippocampal glucocorticoid receptors, and hypothalamicpituitary-adrenal responses to stress. Science 277, 1659-62. 
Liu, E. T. and Lauffenburger, D. A. Systems biomedicine, Academic, Amsterdam.

Liu, J., Naeem, E., Tian, J., Lombardi, V., Kwong, K., Akbari, O., Torday, J. S. and Rehan, V. K. Sexspecific perinatal nicotine-induced asthma in rat offspring. Am J Respir Cell Mol Biol 48, 53-62.

Liu, J., Sakurai, R., O'Roark, E. M., Kenyon, N. J., Torday, J. S. and Rehan, V. K. PPARgamma agonist rosiglitazone prevents perinatal nicotine exposure-induced asthma in rat offspring. Am J Physiol Lung Cell Mol Physiol 300, L710-7.

Mangelsdorf, D. J., Umesono, K., Kliewer, S. A., Borgmeyer, U., Ong, E. S. and Evans, R. M. (1991) A direct repeat in the cellular retinol-binding protein type II gene confers differential regulation by RXR and RAR. Cell 66, 555-61.

Matsushima, A., Kakuta, Y., Teramoto, T., Koshiba, T., Liu, X., Okada, H., Tokunaga, T., Kawabata, S., Kimura, M. and Shimohigashi, Y. (2007) Structural evidence for endocrine disruptor bisphenol A binding to human nuclear receptor ERR gamma. J Biochem 142, 517-24.

McCarty, R. and Lee, J. H. (1996) Maternal influences on adult blood pressure of SHRs: a single pup crossfostering study. Physiol Behav 59, 71-5.

McEwen, B. S. (2007) Physiology and neurobiology of stress and adaptation: central role of the brain. Physiol Rev 87, 873-904.

McGowan, P. O., Sasaki, A., D'Alessio, A. C., Dymov, S., Labonte, B., Szyf, M., Turecki, G. and Meaney, M. J. (2009) Epigenetic regulation of the glucocorticoid receptor in human brain associates with childhood abuse. Nat Neurosci 12, 342-8.

Meaney, M. J., Aitken, D. H., Bodnoff, S. R., Iny, L. J. and Sapolsky, R. M. (1985) The effects of postnatal handling on the development of the glucocorticoid receptor systems and stress recovery in the rat. Prog Neuropsychopharmacol Biol Psychiatry 9, 731-4.

Meerlo, P., Horvath, K. M., Nagy, G. M., Bohus, B. and Koolhaas, J. M. (1999) The influence of postnatal handling on adult neuroendocrine and behavioural stress reactivity. J Neuroendocrinol 11, 925-33.

Nilsson, E. E., Anway, M. D., Stanfield, J. and Skinner, M. K. (2008) Transgenerational epigenetic effects of the endocrine disruptor vinclozolin on pregnancies and female adult onset disease. Reproduction 135, $713-21$.

Ogawa, S., Eng, V., Taylor, J., Lubahn, D. B., Korach, K. S. and Pfaff, D. W. (1998) Roles of estrogen receptor-alpha gene expression in reproduction-related behaviors in female mice. Endocrinology 139, 5070-81.

Oomen, C. A., Girardi, C. E., Cahyadi, R., Verbeek, E. C., Krugers, H., Joels, M. and Lucassen, P. J. (2009) Opposite effects of early maternal deprivation on neurogenesis in male versus female rats. PLoS One 4, e3675.

Phillips, N. K., Hammen, C. L., Brennan, P. A., Najman, J. M. and Bor, W. (2005) Early adversity and the prospective prediction of depressive and anxiety disorders in adolescents. J Abnorm Child Psychol 33, 1324.

Pryce, C. R., Bettschen, D. and Feldon, J. (2001) Comparison of the effects of early handling and early deprivation on maternal care in the rat. Dev Psychobiol 38, 239-51.

Radtke, K. M., Ruf, M., Gunter, H. M., Dohrmann, K., Schauer, M., Meyer, A. and Elbert, T. Transgenerational impact of intimate partner violence on methylation in the promoter of the glucocorticoid receptor. Transl Psychiatry 1, e21.

Raz, L., Khan, M. M., Mahesh, V. B., Vadlamudi, R. K. and Brann, D. W. (2008) Rapid estrogen signaling in the brain. Neurosignals 16, 140-53.

Read, J., van Os, J., Morrison, A. P. and Ross, C. A. (2005) Childhood trauma, psychosis and schizophrenia: a literature review with theoretical and clinical implications. Acta Psychiatr Scand 112, 33050 . 
Rehan, V. K., Liu, J., Sakurai, R. and Torday, J. S. Perinatal nicotine-induced transgenerational asthma. Am J Physiol Lung Cell Mol Physiol 305, L501-7.

Ribeiro, A. C., Musatov, S., Shteyler, A., Simanduyev, S., Arrieta-Cruz, I., Ogawa, S. and Pfaff, D. W. siRNA silencing of estrogen receptor-alpha expression specifically in medial preoptic area neurons abolishes maternal care in female mice. Proc Natl Acad Sci U S A 109, 16324-9.

Ridder, S., Chourbaji, S., Hellweg, R., Urani, A., Zacher, C., Schmid, W., Zink, M., Hortnagl, H., Flor, H., Henn, F. A., Schutz, G. and Gass, P. (2005) Mice with genetically altered glucocorticoid receptor expression show altered sensitivity for stress-induced depressive reactions. $J$ Neurosci 25, 6243-50.

Riu, A., Grimaldi, M., le Maire, A., Bey, G., Phillips, K., Boulahtouf, A., Perdu, E., Zalko, D., Bourguet, $\mathrm{W}$. and Balaguer, P. Peroxisome proliferator-activated receptor gamma is a target for halogenated analogs of bisphenol A. Environ Health Perspect 119, 1227-32.

Rosenblatt, J. S. (1994) Psychobiology of maternal behavior: contribution to the clinical understanding of maternal behavior among humans. Acta Paediatr Suppl 397, 3-8.

Rosenblatt, J. S. and Ceus, K. (1998) Estrogen implants in the medial preoptic area stimulate maternal behavior in male rats. Horm Behav 33, 23-30.

Rousseau, G. G. and Baxter, J. D. (1979) Glucocorticoid receptors. Monogr Endocrinol 12, 49-77.

Ruff, M., Gangloff, M., Wurtz, J. M. and Moras, D. (2000) Estrogen receptor transcription and transactivation: Structure-function relationship in DNA- and ligand-binding domains of estrogen receptors. Breast Cancer Res 2, 353-9.

Sakurai, R., Cerny, L. M., Torday, J. S. and Rehan, V. K. Mechanism for nicotine-induced up-regulation of Wnt signaling in human alveolar interstitial fibroblasts. Exp Lung Res 37, 144-54.

Salian, S., Doshi, T. and Vanage, G. (2009) Impairment in protein expression profile of testicular steroid receptor coregulators in male rat offspring perinatally exposed to Bisphenol A. Life Sci 85, 11-8.

Sapolsky, R. M., Krey, L. C. and McEwen, B. S. (1984) Stress down-regulates corticosterone receptors in a site-specific manner in the brain. Endocrinology 114, 287-92.

Sato, K., Fukata, H., Kogo, Y., Ohgane, J., Shiota, K. and Mori, C. (2006) Neonatal exposure to diethylstilbestrol alters the expression of DNA methyltransferases and methylation of genomic DNA in the epididymis of mice. Endocr J 53, 331-7.

Sato, K., Fukata, H., Kogo, Y., Ohgane, J., Shiota, K. and Mori, C. (2009) Neonatal exposure to diethylstilbestrol alters expression of DNA methyltransferases and methylation of genomic DNA in the mouse uterus. Endocr J 56, 131-9.

Schneider, S., Kaufmann, W., Buesen, R. and van Ravenzwaay, B. (2008) Vinclozolin--the lack of a transgenerational effect after oral maternal exposure during organogenesis. Reprod Toxicol 25, 352-60.

Schwabe, J. W., Neuhaus, D. and Rhodes, D. (1990) Solution structure of the DNA-binding domain of the oestrogen receptor. Nature 348, 458-61.

Siegel, H. I. and Rosenblatt, J. S. (1975) Hormonal basis of hysterectomy-induced maternal behavior during pregnancy in the rat. Horm Behav 6, 211-22.

Stouder, C. and Paoloni-Giacobino, A. Transgenerational effects of the endocrine disruptor vinclozolin on the methylation pattern of imprinted genes in the mouse sperm. Reproduction 139, 373-9.

Takayanagi, S., Tokunaga, T., Liu, X., Okada, H., Matsushima, A. and Shimohigashi, Y. (2006) Endocrine disruptor bisphenol A strongly binds to human estrogen-related receptor gamma (ERRgamma) with high constitutive activity. Toxicol Lett 167, 95-105.

Tsigos, C. and Chrousos, G. P. (2002) Hypothalamic-pituitary-adrenal axis, neuroendocrine factors and stress. J Psychosom Res 53, 865-71. 
Vallee, M., Mayo, W., Dellu, F., Le Moal, M., Simon, H. and Maccari, S. (1997) Prenatal stress induces high anxiety and postnatal handling induces low anxiety in adult offspring: correlation with stress-induced corticosterone secretion. J Neurosci 17, 2626-36.

Varayoud, J., Ramos, J. G., Bosquiazzo, V. L., Munoz-de-Toro, M. and Luque, E. H. (2008) Developmental exposure to Bisphenol a impairs the uterine response to ovarian steroids in the adult. Endocrinology 149, 5848-60.

Wagner, C. K. and Morrell, J. I. (1996) Levels of estrogen receptor immunoreactivity are altered in behaviorally-relevant brain regions in female rats during pregnancy. Brain Res Mol Brain Res 42, 328-36.

Wang, C., Fu, M., Angeletti, R. H., Siconolfi-Baez, L., Reutens, A. T., Albanese, C., Lisanti, M. P., Katzenellenbogen, B. S., Kato, S., Hopp, T., Fuqua, S. A., Lopez, G. N., Kushner, P. J. and Pestell, R. G. (2001) Direct acetylation of the estrogen receptor alpha hinge region by p300 regulates transactivation and hormone sensitivity. J Biol Chem 276, 18375-83.

Wang, Z., Benoit, G., Liu, J., Prasad, S., Aarnisalo, P., Liu, X., Xu, H., Walker, N. P. and Perlmann, T. (2003) Structure and function of Nurr1 identifies a class of ligand-independent nuclear receptors. Nature $423,555-60$.

Watts, A. G. (2005) Glucocorticoid regulation of peptide genes in neuroendocrine CRH neurons: a complexity beyond negative feedback. Front Neuroendocrinol 26, 109-30.

Weaver, I. C., Cervoni, N., Champagne, F. A., D'Alessio, A. C., Sharma, S., Seckl, J. R., Dymov, S., Szyf, M. and Meaney, M. J. (2004) Epigenetic programming by maternal behavior. Nat Neurosci 7, 847-54.

Xu, H. E., Lambert, M. H., Montana, V. G., Parks, D. J., Blanchard, S. G., Brown, P. J., Sternbach, D. D., Lehmann, J. M., Wisely, G. B., Willson, T. M., Kliewer, S. A. and Milburn, M. V. (1999) Molecular recognition of fatty acids by peroxisome proliferator-activated receptors. Mol Cell 3, 397-403.

Zhang, X., Tanaka, K., Yan, J., Li, J., Peng, D., Jiang, Y., Yang, Z., Barton, M. C., Wen, H. and Shi, X. Regulation of estrogen receptor alpha by histone methyltransferase SMYD2-mediated protein methylation. Proc Natl Acad Sci U S A 110, 17284-9. 
Table 1

Concentration of BPA and ftaletes in some experiments were transgenerational effects were shown

\begin{tabular}{|c|c|c|c|c|}
\hline Agent and dose & Experimental system & Observation & Mechanism & Reference \\
\hline $\mathrm{BPA}(50 \mathrm{mg} / \mathrm{kg})$ & $\begin{array}{l}\text { Avy mouse, maternal exposure to BPA alters the } \\
\text { adult phenotype of the offspring. }\end{array}$ & $\begin{array}{l}\text { Shifted the coat color distribution of viable yellow } \\
\text { mouse offspring toward yellow. }\end{array}$ & $\begin{array}{l}\text { Decreasing CpG methylation in the IAP retrotransposable sequence inserted } \\
\text { upstream of the Agouti gene. }\end{array}$ & Dolinoy 2007 \\
\hline BPA $(0.1 \mu \mathrm{g} / \mathrm{pup})$ & $\begin{array}{l}\text { Rats exposed to BPA on postnatal days } 1 \text { to } 5 \text { and } \\
\text { prostates investigated at adult age ( } 28 \text { weeks). }\end{array}$ & $\begin{array}{l}\text { During the neonatal developmental period susceptibility } \\
\text { to precancerous prostatic lesions is increased. }\end{array}$ & Altered methylation patterns of several candidate genes e.g. Pde $4 \mathrm{~d} 4$. & Ho 2006 \\
\hline BPA (1.2 and $2.4 \mu \mathrm{g} / \mathrm{kg} / \mathrm{day}$ ) & $\begin{array}{l}\text { Perinatal exposure to BPA of female rats } \\
\text { investigation on the testes of male adult } \\
\text { offsnrings. }\end{array}$ & $\begin{array}{l}\text { Subfertility and decreased sperm count and motility } \\
\text { were observed in the F2 and F3 generations. }\end{array}$ & $\begin{array}{l}\text { Significant decrease in the testicular expression profile of SRC-1 and NCoR, } \\
\text { with an increase in the expression of p/CIP and GRIP- } 1 \text {. }\end{array}$ & Salian 2009 \\
\hline BPA $(25 \mu \mathrm{g} / \mathrm{kg})$ DES $(5 \mu \mathrm{g} / \mathrm{kg})$ & $\begin{array}{l}\text { Investigations on breast cancer cells and on the } \\
\text { mammary glands of ovariectomized rats. }\end{array}$ & $\begin{array}{l}\text { Treatment may result in adverse health effects including } \\
\text { cancer and other hormonally regulated disorders. }\end{array}$ & $\begin{array}{l}\text { Recruitment of ERs and ER-coregulators (MLL1, MLL3, CBP and p300) to the } \\
\text { HOTAIR promoter. Changes in the epigenetic modifications (histone H3K4- } \\
\text { trimethvlation. histone acetvlation) leading to HOTAIR dvsregulation. }\end{array}$ & Bhan 2014 \\
\hline BPA $(5 \mathrm{mg} / \mathrm{kg})$ & $\begin{array}{l}\text { Exposure to BPA of mice in utero, investiations on } \\
\text { female offspring uterus (at } 2 \text { or } 6 \text { weeks after } \\
\text { birth). }\end{array}$ & Altered Hoxa10 expression in uterus. & $\begin{array}{l}\text { Decreased methylation of the HoxalO gene led to increased ER binding to the } \\
\text { ERE both in vitro and in vivo and rendered the ERE more estrogen responsive. }\end{array}$ & Bromer 2010 \\
\hline DES $(10 \mu \mathrm{g} / \mathrm{kg})$ & $\begin{array}{l}\text { Exposure to DES of mice in utero, investiations } \\
\text { on female offspring uterus (at } 2 \text { or } 6 \text { weeks after } \\
\text { birth). }\end{array}$ & Altered Hoxa10 expression in uterus. & $\begin{array}{l}\text { Aberrant methylation in the promoter and intron of Hoxa10; increased levels of } \\
\text { mRNA expression of two important DNMTs. }\end{array}$ & Bromer 2009 \\
\hline BPA $(2.4 \mu \mathrm{g} / \mathrm{kg})$ & $\begin{array}{l}\text { Neonatal exposure to BPA. Investigations on testis } \\
\text { in adult rats. }\end{array}$ & Adverse effects on male fertility. & $\begin{array}{l}\text { Hypermethylation of the promoter region of ERalpha and Erbeta. Increased } \\
\text { expression of Dnmts. }\end{array}$ & Doshi 2011 \\
\hline $\mathrm{BBP}$ and DBP & $\begin{array}{l}\text { MCF-7 and MCF10A human breast cancer cell } \\
\text { lines. }\end{array}$ & $\begin{array}{l}\text { Hypermethylation of promoter } \mathrm{CpG} \text { islands contributes } \\
\text { to the loss of gene function of several tumor-related } \\
\text { genes. including ERs. }\end{array}$ & $\begin{array}{l}\text { DNA hypomethylation or -demethylation may modulate the expression of a CpG- } \\
\text { island-associated gene (ERalpha). }\end{array}$ & Kang 2005 \\
\hline DES (3 $\mu \mathrm{g} / \mathrm{pup})$ & $\begin{array}{l}\text { DES administration to neonatal mice at days } 5,14 \\
\text { and } 30 \text {. Uteri were excised. }\end{array}$ & $\begin{array}{l}\text { Altered expression of DNMT-s and DNA methylation on } \\
\mathrm{Sp} 1 \text { and } \mathrm{Sp} 3 \text { in uterus and epididymis. }\end{array}$ & Changes in methylation patterns. & Sato 2006, 2009 \\
\hline
\end{tabular}


Non-genomic pathway

\section{Genomic pathway}

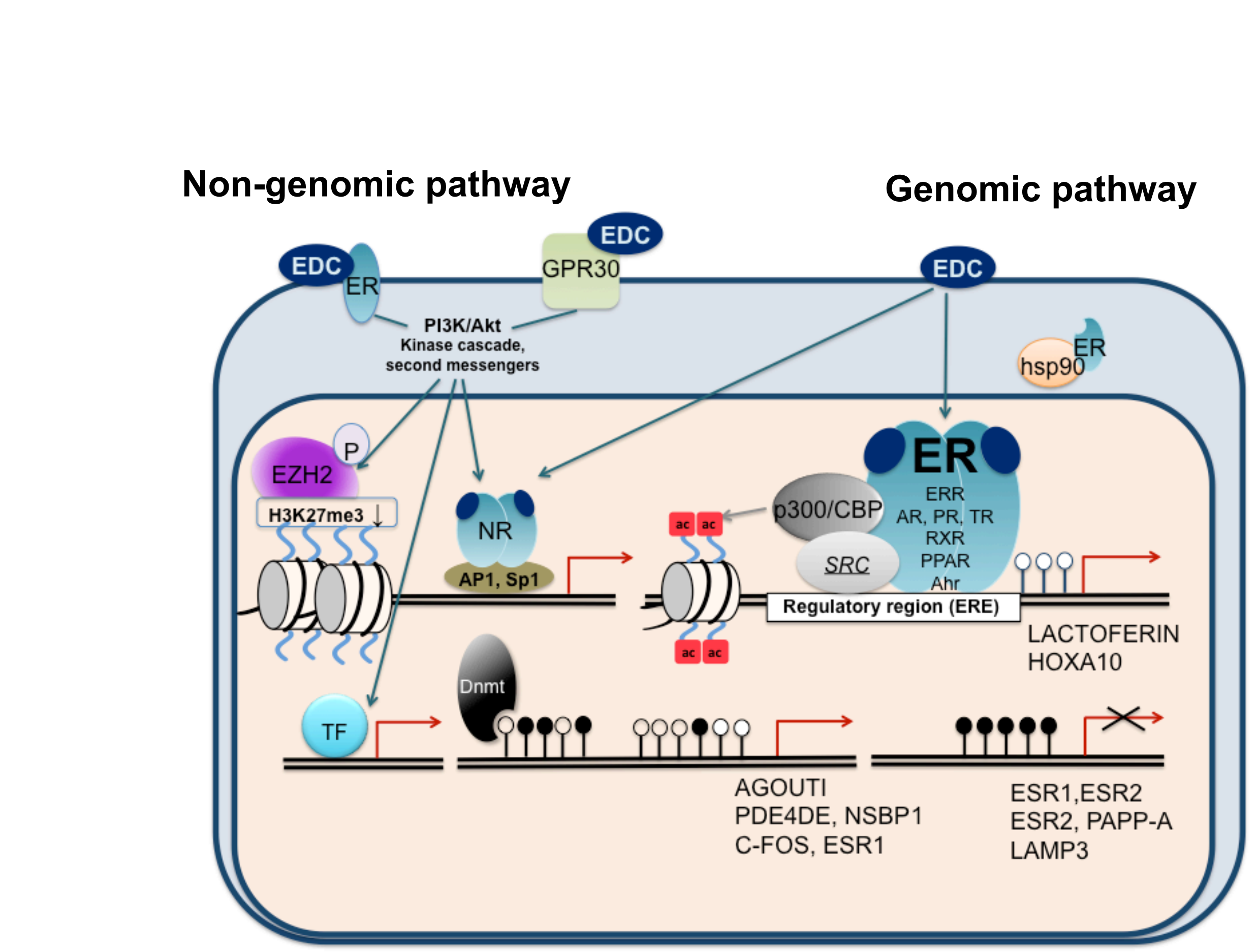




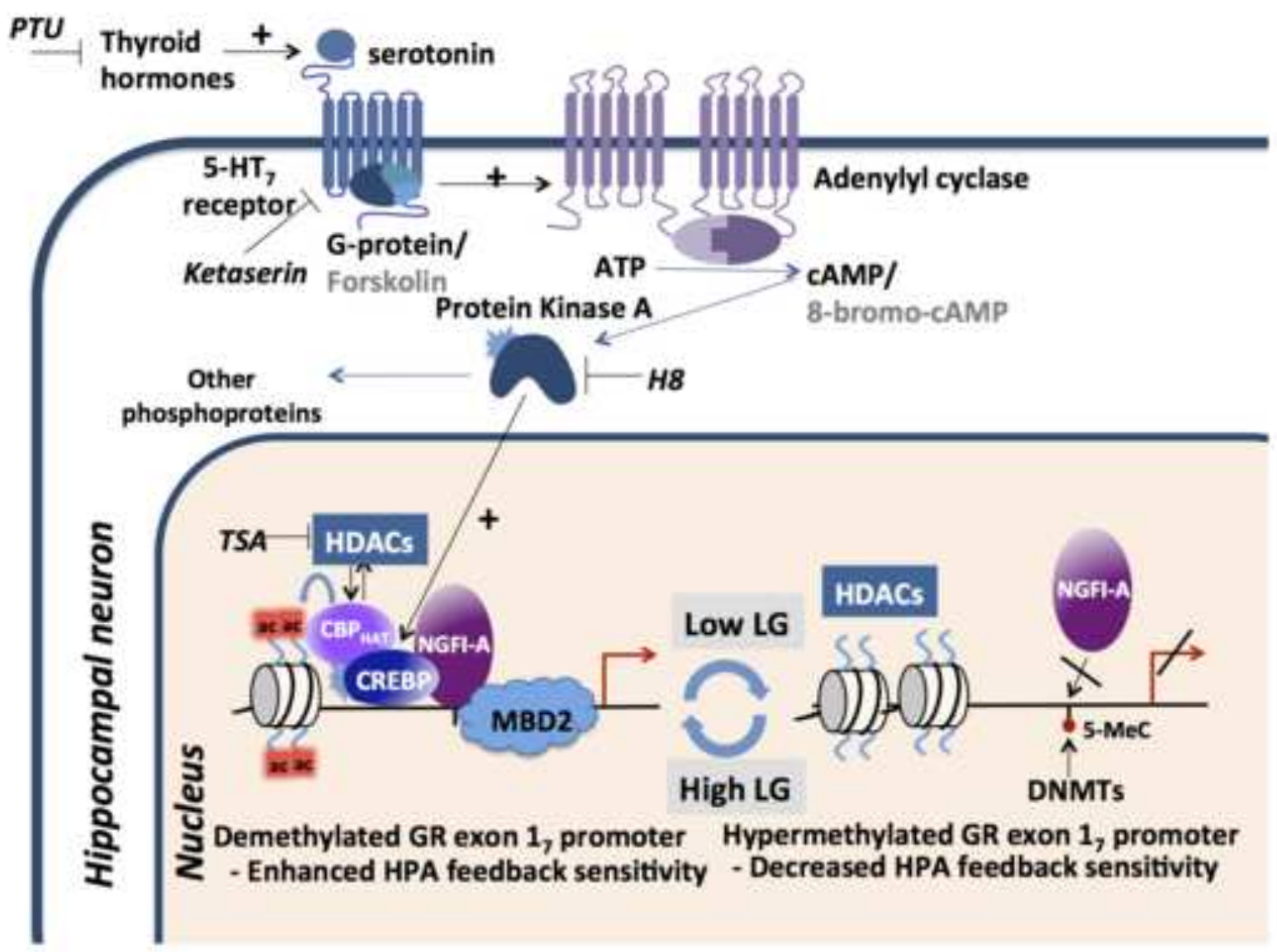

